The Polish Journal of the Arts and Culture. New Series 4

(2/2016): 7-25 [ARTYKUE]

DOI: $10.4467 / 24506249$ PJ.16.008.6239

\title{
Opisać nieopisywalne, czyli literackie ujęcie sansary i nirwany w twórczości Wiktora Pielewina
}

\author{
Aleksandra ImosA
}

\begin{abstract}
Streszczenie
Artykuł sytuuje się na styku literaturoznawstwa i kulturoznawstwa, gdyż dotyczy metod zaprezentowania wątków buddyjskich w beletrystyce. Analiza opiera się na wybranych powieściach i opowiadaniach autorstwa współczesnego rosyjskiego pisarza Wiktora Pielewina. Rozważania (paradoksalnie) dotyczą prób językowego ujęcia nieopisywalnego zjawiska jakim jest oświecenie.
\end{abstract}

Słowa kluczowe: Wiktor Pielewin, buddyzm, oświecenie, nirwana, sansara

Aleksandra Imos A komparatystka cywilizacji, studentka filologii romańskiej na Uniwersytecie Jagiellońskim, jej zainteresowania badawcze obejmują przede wszystkim analizę wątków buddyjskich we współczesnej literaturze, obecnie zajmuje się także analizą opisu buddyzmu, chrześcijaństwa nestoriańskiego oraz islamu w pochodzącym z XIII w. „Opisie świata” („Le Devisement du monde”) Marco Polo.

Afiliacja: Instytut Filologii Romańskiej, Uniwersytet Jagielloński, Kraków, Polska

E-MAIL: imosa.aleksandra@gmail.com 
Cesse de parler comme un homme qui rêve. Georges Perec, Un homme qui dort ${ }^{1}$

Metafora snu widoczna jest w buddyzmie... już w samej nazwie 2 . Pochodzi ona przecież od określenia Budda, czyli „przebudzony”, a i w języku polskim rdzeń budh można odnaleźć w słowie „budzić” oraz w jego derywatach. Podobnie jest w języku rosyjskim; tam napotykamy słowo budit'. Ten potencjał językowy niewątpliwie zainspirował jednego z najbardziej znanych współczesnych rosyjskich pisarzy, Wiktora Olegowicza Pielewina (ur. 1962), do stworzenia całej serii obrazów opartej na owej przenośni. Ten wiązany najczęściej z nurtem postmodernistycznym twórca pracuje nad materią językową w niezwykle świadomy i zręczny sposób, bawi się także nawiązaniami kulturowymi, konstruując bardzo złożone światy przedstawione, w których nachodzą na siebie różne poziomy rzeczywistości. W niniejszym artykule nie będę się jednak zajmować postmodernistycznymi aspektami utworów rosyjskiego prozaika, którym to należałoby poświęcić osobną pracę, ale odwołam się do szeroko obecnych w jego twórczości inspiracji buddyjskich. Wychodząc od rzeczonej metafory snu jako sansarycznego stanu umysłu, przejdę do prób literackiego ujęcia doświadczenia wyzwolenia się z kręgu narodzin i śmierci. W swoich rozważaniach sięgnę do dwóch powieści Pielewina, $\mathrm{Ma}$ łego palca Buddy3 (wyd. 2003) i T (wyd. 2012), a także do dwóch opowiadań, SPI (wyd. 2008 w zbiorze opowiadań Kryształowy świat ${ }^{4}$ ) oraz Żótta strzała (wyd. 2007 w Omon Ra i inne opowieści).

Jak czytamy w pierwszym z wymienionych tekstów: „Przecież to jedna z najbardziej znanych historii na Ziemi. Był niegdyś pewien człowiek, który nie potrafił żyć tak, jak inni. Próbował zrozumieć, co to właściwie jest - to, co dzieje się z nim dzień w dzień - i kim jest on sam: ten, z którym to się dzieje. I oto pewnej nocy, w październiku, gdy siedział pod koroną drzewa, podniósł wzrok ku niebu i zobaczył jasno świecącą gwiazdę. I w tym właśnie mgnieniu

1 „Przestań mówić jak człowiek, który śni” - zob. G. Perec, Un homme qui dort, Paris 1967, s. 162 [tłum. własne].

2 Zaznaczając, iż sama nazwa „buddyzm” powstała na Zachodzie. Por. V. Zotz, Historia filozofii buddyjskiej, Wydawnictwo WAM, Kraków 2007, s. 36.

$3 \mathrm{~W}$ oryginale powieść ta zatytułowana jest Czapajew i Pustota.

4 Pierwotnie pochodzi ze zbioru opowiadań Żettaja strieła (Źótta strzała) z 1992. W języku angielskim zostało umieszczone w zbiorze $A$ Werewolf Problem in Central Russia: And Other Stories (wyd. 1998) pod tytułem Sleep. 
zrozumiał wszystko"5. Jest to oczywiście historia Gautamy Siddharthy, który doświadczył bezpośredniego wglądu w naturę umysłu i rzeczywistości, czyli „przebudzenia” (bodhi). Tradycja przyjmuje, iż doszło do tego wydarzenia, gdy Budda Śakjamuni siedział pod wielkim figowcem pagodowym nazywanym później z tej okazji Drzewem Bodhi (Ficus religiosa) ${ }^{6}$. Medytował tam, aż pewnego świtu, czyli w czasie, kiedy widoczna jest Wenus zwana także Gwiazdą Zaranną, stał się buddą, osiągając pełną świadomość pierwotną. Umiejscowienie historii w październiku jest ze strony Pielewina zabiegiem literackim nadającym sens przyznawaniu w powieści Orderu Gwiazdy Październikowej istotom przebudzonym. Ściślej rzec ujmując, nikt nie zajmuje się rozdawaniem takich odznaczeń, a ci, którym one przysługują, po prostu wiedzą, że mogą zacząć je już nosić. Gwiazda symbolizuje właśnie moment osiągnięcia bodhi.

Ten sam rdzeń odnajdujemy także w słowie bodhisattwa, czyli „istota przebudzona" pozostająca jednak w kręgu sansary dla wyzwolenia innych istot czujących. Jak to Pielewin dalej opisuje w Matym palcu Buddy, motywacja buddów i bodhisattwów łączy się z płonącym od chwili przebudzenia Śakjamuniego „ogniem miłosierdzia dla wszystkich żywych istot, ogniem, którego nawet w przypadku służbowej konieczności nie można zgasić całkowicie"?.

W T jeden z bohaterów, Urgan Dżambon Tulku, mówi, iż: „Nauka Buddy nie polega na zestawie komunałów, które od dwóch tysięcy lat redagują zapasieni klasztorni biurokraci, ale na tym, żeby się przeprawić na Drugi Brzeg na dowolnym dostępnym środku pływającym"8. Słowa te odnoszą się do porównania przez Śakjamuniego swoich nauk do tratwy, przez co kładzie nacisk na ich relatywne znaczenie - cel jest jeden i jest nim owy „Drugi Brzeg [sansary]”. Nie można przywiązywać się do czegoś, co jest jedynie narzędziem do wyzwolenia, a i te środki (upaja) mogą być przeróżne, gdyż powinny być dostosowane do indywidualnych możliwości adepta. Wiąże się to z kolejną parabolą, tym razem zawartą w Saddharmapundarikasutrze, czyli Sutrze Lotosu dobrego Prawa zwanej w skrócie Sutra Lotosu. Jest to historia bogatego mężczyzny, pod którego nieobecność dom staje w płomieniach.

5 W. Pielewin, Maty palec Buddy, Wyd. I, Wydawnictwo W.A.B., Warszawa 2003, s. 256.

${ }^{6}$ W 1956 r. Bandido Chambo Lama Dżimbal Dorżi Gombojew zasadził na terenie Dacanu Iwołgińskiego nasiona pochodzące z Drzewa Bodhi. Odbyło się to z okazji 2500. rocznicy parinirwany Buddy Śakjamuniego.

7 Ibidem, s. 256-257 - cyt. zmodyf.

8 Idem, T., Wyd. I, Wydawnictwo W.A.B., Warszawa 2012, s. 327. 
Wewnątrz pozostają jego dzieci, nieświadome śmiertelnego zagrożenia. Nie zwracają uwagi na krzyki zaniepokojonego ojca, każącego im natychmiast wyjść. Następnym jego krokiem jest zaproponowanie dzieciom cudownych zabawek, aby zachęcić je do opuszczenia domu. Tym razem udaje się je uratować. Świat jest właśnie jak ten płonący dom, z którego ludzie nie chcą uciekać, gdyż nie widzą zagrożenia. Budda natomiast proponuje różne sposoby, aby ich zachęcić do wyjścia. I tym razem nacisk jest położony na fakt, iż dążenia prowadzą tylko do jednego celu, chociażby był on przedstawiany w różnych wariantach. Również do tej opowieści odnosi się Wiktor Olegowicz:

- Zaprawdę - ze smutkiem odezwał się Wołodin - ten świat jest na podobieństwo płonącego domu.

- Jaki tam płonący dom - ochoczo zaoponował Szurik. - Pożar w burdelu podczas powodzi. ${ }^{9}$

Pisarz dosadnie ujmuje tę metaforę, dorzucając do niej własne, przejaskrawione porównanie do „pożaru w burdelu podczas powodzi”. Poziom niewiedzy i wszechobecna możliwość środków do jej wyzbycia się są tu genialnie skontrastowane. Ów dom schadzek może tu podkreślać jeszcze pożądanie charakterystyczne szczególnie dla tych, którzy odrodzili się w ludzkim ciele. Natomiast szalejąca wokół powódź, ogromna ilość wody mogącej ugasić ten pożar, być może wskazuje na aktualną „bliskość” metod prowadzących do wyzwolenia - kiedy zaspokojenie podstawowych potrzeb życiowych staje się coraz łatwiejsze, częściej zaczynamy przyglądać się kwestiom związanym z duchowością i szukamy rozwiązań niezauważanych wcześniej problemów. Ponadto Czapajew w tej samej powieści stwierdza, iż: „Tak już jest urządzony ten świat, że na wszystkie pytania wypada nam odpowiadać pośród płonącego domu"10. Właśnie na poziomie sansary nieznana jest zamroczonemu umysłowi natura rzeczywistości. Po wyjściu z płonącego domu nie ma już żadnych pytań.

Przyjrzę się teraz bliżej bohaterowi, który tkwi w „płonącym domu”, w którym wszyscy śpią. Odwołuję się tu do opowiadania SPI umieszczonego w zbiorze Kryształowy świat. Tytuł to skrót nazwy Sojuzpłodimport, czyli spółki zajmującej się handlem produktami alkoholowymi, w tym eksportem tradycyjnej rosyjskiej wódki (Stolicznaja, Moskowskaja). Założona w latach

9 Idem, Maty palec Buddy, s. 301.

${ }^{10}$ Ibidem, s. 345 . 
6o-tych, początkowo należała do państwa, natomiast z początkiem lat 9otych uległa prywatyzacji. Na tym etapie historii spółki się zatrzymam, gdyż analizowane przez mnie opowiadanie pochodzi właśnie z początku ostatniej dekady XX w. Jednocześnie rosyjskie spi to „śpij”, na którym to aspekcie tytułu skupili się anglojęzyczni tłumacze nazywając utwór Sleep.

Główny bohater to Nikita Sonieczkin. Również jego nazwisko jest znaczące: rosyjskie słowo son oznacza „sen”, a sonieczka to deminutyw od słowa „śpioch" „słońce” będące symbolem wiedzy, która rozświetla mroki niewiedzy. Wydaje się jednak, że to raczej pojęcie snu determinuje los protagonisty, którego poznajemy, gdy jest w trakcie trzeciego semestru studiów. Dokonuje on wtedy odkrycia, że wszyscy wokół niego śpią. Początkowo obserwuje uczucie senności dopadające go podczas wykładów z filozofii marksizmu i leninizmu. Potem zauważa, iż zasypiają nie tylko inni studenci, ale i sami profesorowie: „wykładowca, który miał zwyczaj opierać się mocno o wysoką katedrę, od czasu do czasu przewraca się na drugi bok, plecami do audytorium i twarzą do tablicy (aby jakoś uzasadnić swą nieuprzejmą pozę, ospale wymachiwał ręką w kierunku wypisanych kredą punktów wykładu) (...) - większość wykładów jednak wygłaszał na prawym boku"12. Bohater uczy się mechanizmów „normalnego” zachowania podczas snu, tzn. aktywnego uczestnictwa w seminariach, kontaktów towarzyskich, wtedy to koledzy z uczelni zaczynają darzyć go sympatią, przestają uznawać za dziwaka. Również jego relacje z rodzicami znacząco poprawiają się od momentu, kiedy zaczyna praktycznie nieustannie spać. Jego matka kwituje to słowami: „Ty się po prostu odrodziłeś do życia!"'13. Większość aspektów działalności ludzkiej staje się dla bohatera łatwiejsza i przynosi lepsze niż dotychczas rezultaty. We śnie wykonuje on wszystko mechanicznie, bezrefleksyjnie, co daje pozytywne skutki na poziomie życia codziennego. W celu sprawdzenia, czy sam w danej chwili śpi czy nie, Nikita zaczyna nosić przy sobie szpilkę. W końcu Sonieczkin widzi, że ludzie żyją, śpiąc, nie tylko na uczelni czy u niego w domu, ale wszędzie - na ulicach, w metrze. Niektórzy głośno chrapią lub wykonują gesty poprawiania poduszki pod głową, po innych zaś na pierwszy rzut oka nie da się poznać, iż są w objęciach Morfeusza. Zauważa, że niektórzy zasy-

${ }^{11} \mathrm{~W}$ przypadku wersji angielskiej tłumacz przełożył nazwisko protagonisty na Dozakin pochodzące od doze, czyli „drzemka”.

${ }^{12}$ Idem, SPI [w:] W. Pielewin, Kryształowy świat, Wyd. I, Wydawnictwo W.A.B., Warszawa 2008, s. 280.

${ }^{13}$ Ibidem, s. 285 . 
piają mocniej od innych, całkowicie odcinając się od otoczenia, nazywa to „chwilowym niebytem”. Praca telewizji także ma działanie nasenne, chociażby emitując „historyczne wspólne zasypianie”.

Bohatera zaczyna przepełniać uczucie samotności na myśl, że nie wie, co śni się innym ludziom oraz dlaczego wszyscy w ogóle ciągle śpią. Z kolei te wątpliwości rodzą w nim strach związany z samą próbą szukania odpowiedzi. Temat wydaje się absolutnie zakazany, nikt o nim nigdy nie wspomina, jest „niedomówieniem istnienia”. Kwestia ta wywołuje nawet u protagonisty dziwny sen, który pojawia się, kiedy robi on zakupy w uniwersamie. Dochodzi zatem do nałożenia się dwóch rzeczywistości: szarej prozy życia w postaci wizyty w sklepie oraz onirycznych fantazmatów. Owo senne marzenie dotyczy próby powołania specjalnej komisji odpowiedzialnej za ogłoszenie prawdy (a może nawet Prawdy). Warto zwrócić uwagę, iż słowo „uniwersam” brzmi niebezpiecznie podobnie do „uniwersum”. Może to implikować fakt, że we śnie Sonieczkina będą podejmowane decyzje uniwersalne, dotyczące całej ludzkości, wszechświata. Trójka wybranych członków wspomnianej komisji zamyka się w pokoju na obradach. Po usłyszeniu głośnego trzasku i późniejszym braku odpowiedzi z wnętrza pomieszczenia, reszta obecnych wyważa drzwi. W środku znajdują trzy garnitury, wypalone od wewnątrz. Ogólna konsternacja i przestrach zostają przerwane, gdy „wypalona” trójka powraca mówiąc, iż był to jedynie żart. Wściekły bohater, przytłoczony niewiedzą i samotnością, postanawia bez względu na niebezpieczeństwo podjąć dyskusję na temat snu. Rozmówcy zaczyna szukać na obrzeżach miasta, gdzie nie ma tak wielu patroli milicyjnych.

Po nieudanych próbach nawiązania kontaktu, Nikita kończy, siedząc na ławce $\mathrm{z}$ dwoma ormowcami i pijąc wódkę. Ta opatrzona jest emblematem tytułowego Sojuzpłodimportu, czyli podobną do gałki ocznej kulą ziemską. Akurat ta butelka alkoholu jest przeznaczona na eksport i na etykiecie zawiera napisy w alfabecie łacińskim. Co więcej, dopiero po tej scenie czytelnik dowiaduje się, że Sonieczkin również jest ormowcem, założył już własną rodzinę, wypełnia model życiowy przedstawiciela klasy średniej. Wcześniej można mieć wrażenie, że ciągle jest studentem mieszkającym u rodziców. Okazuje się jednak, że rozbudzone na uczelni wątpliwości dotyczące natury rzeczywistości nie zostały przez bohatera rozwiązane, nie uchroniły go też przed kolektywnym śnieniem. Ostatecznym momentem poddania się bohatera jest chwila, w której wyrzuca szpilkę - znak, iż odrzuca możliwość przebudzenia. 
Dzieje się to po tym jak bohater wysiada z metra. Będąc jeszcze w środku, zauważa napisane na szybie od zewnętrznej strony słowo „tak”. W oryginale jest to $d a$, które widziane z perspektywy bohatera daje $a d$, co po rosyjsku oznacza „piekło” ${ }^{4}$. To właśnie śni Sonieczkin wraz ze swoimi współobywatelami.

Pojawiająca się po scenie $\mathrm{z}$ ormowcami jeszcze kilkukrotnie, jako element życia codziennego w Rosji, wódka może być symbolem omroczenia, czynnikiem wprowadzającym w stan snu. Nieprzypadkowo jest to towar eksportowy, a logo SPI przedstawia kulę ziemską. Wyraźnie mamy tu do czynienia z nawiązaniami uniwersalistycznymi.

Ów „sen” można rozpatrywać w kategoriach społeczno-politycznych, biorąc pod uwagę rosyjską stagnację w okresie ustroju komunistycznego. Zważywszy na wielość kontekstów u Pielewina, szczególnie metafizycznych, i jego niechęć do drobiazgowego wyróżniania treści o charakterze narodowym, przedstawię interpretację opisywanego zjawiska w świetle filozofii buddyjskiej. Chodzi tu o analogię doświadczenia potocznego i marzenia sennego.

Obudzenie się dotyczy właśnie snu ignorancji, który jest stanem, w jakim większość istot spędza swoje życie. Wynika on z niewiedzy, czyli błędnego postrzegania rzeczywistości ${ }^{15}$. Tak rozumiem właśnie ostateczne położenie Nikity Sonieczkina. W opowiadaniu występuje kilka poziomów snu. Czytelnik poznaje protagonistę w momencie, gdy ten spostrzega, że na co dzień zaczyna odczuwać coraz większą senność. Poprzez zauważenie samego snu bohater ma szansę na „przebudzenie”. Dokładnie obserwuje fazy, w jakich się znajduje; wyróżnia momenty „snu” i „jawy”, analizuje zachowanie swoje oraz otaczających go ludzi. Nawet początkowe noszenie przy sobie szpilki jest próbą pracy nad sobą. Jednak złudne poczucie większego sukcesu w postaci lepszych kontaktów osobistych czy efektywniejszego (choć mechanicznego) wykonywania codziennych czynności w połączeniu z niemożnością odnalezienia odpowiedzi na pytania związane z kwestią snu doprowadzają Sonieczkina do pogrążenia się we śnie.

${ }^{14}$ Zarówno w polskim, jak i w angielskim przekładzie, ten fakt został pominięty, nie ma nawet stosownych przypisów od tłumaczy. Bardzo ciekawe rozwiązanie tej nieprzetłumaczalnej gry słów w wersji angielskiej proponuje Alexandra Berlina. Autorka sugeruje wykorzystanie widocznego za oknem szyldu stacji paliw Shell z przesłoniętą pierwszą literą, co pozostawia słowo hell, czyli właśnie „piekło”. Por. A. Berlina, Russian Magical Realism and Pelevin as Its Exponent, „Comparative Literature and Culture” 11 (4/2009), [www 01]

${ }^{15}$ Zob. A. Imosa, Buddyzm w literaturze na przykładzie opowiadania „Iwan Kublachanow” Wiktora Pielewina, „Ogrody Nauk i Sztuk” 5 (2015), s. 536-537, [www 02]. 
Kwestia rozdzielenia „snu” od „jawy” oraz związana z tym niepewność trwałej tożsamości jest także jednym z punktów zbieżnych dla nauk buddyjskich i taoistycznych. Znana jest opowieść o śnie jednego z najważniejszych mistrzów taoizmu, Zhuangzi, żyjącego na przełomie IV/III w. p.n.e. W tym śnie mędrzec był szczęśliwym motylem nieświadomym istnienia mężczyzny, jednak po chwili obudził się i znów był sobą. Doprowadziło to do wątpliwości czy to Zhuangzi śnil, że jest motylem, czy to motyl śnił, że jest mistrzem Zhuangzi. Historia ta znana jest również Pielewinowi i z charakterystycznym dla siebie poczuciem humoru autor wykorzystuje ją, dostosowując do odmiennych realiów polityczno-społecznych: „(...) znałem niegdyś pewnego chińskiego komunistę - nazywał się Tsy-Czuang. Śniło mu się często, że jest czerwonym motylem, latającym pośród traw. I kiedy się budził, nie mógł pojąć, czy to motylowi przyśniło się, że zajmuje się działalnością rewolucyjną, czy też konspirator widział we śnie, że fruwa wśród kwiatów"16.

W SPI spotykamy się z zaznaczeniem kwestii „śnienia” jako omroczenia, z którego Sonieczkin nie jest w stanie się wyrwać. W Matym palcu Buddy Wasilij Czapajew tak oto przedstawia powodowaną niewiedzą sansarę: „Jeśli obudzą cię, Pietka, z twoich koszmarów (...), nie otwierając oczu - to trafisz tylko z jednego snu w drugi. I będziesz tak wędrował całą wieczność. Ale jeśli zrozumiesz, że absolutnie wszystko, co się z tobą dzieje, to po prostu sen, wtedy to, co ci się przyśni, przestanie być ważne. I kiedy się w końcu obudzisz, obudzisz się już naprawdę. I na zawsze" ${ }^{17}$. Chodzi tu o fakt, który można ująć jako „otwarcie oczu” pomiędzy jednym snem a drugim. Dopiero tak opisane zrozumienie pozwala ujrzeć sansaryczne odrodzenia właśnie jako sny. Natomiast w opowiadaniu Źótta Strzała ${ }^{18}$ Pielewin odwołuje się do innej ciekawej metafory: zamiast snu przywołuje jazdę koleją, a wysiadanie z pociagu przedstawia jako przebudzenie ${ }^{19}$.

Motyw tytułowej żółtej strzały pojawia się w utworze kilkukrotnie. Po pierwsze, chodzi o promienie słoneczne, które protagonista imieniem Andriej obserwuje, jedząc śniadanie w wagonie restauracyjnym: „Gorące świa-

${ }^{16}$ Idem, Maty palec Buddy, s. 242.

${ }^{17}$ Ibidem, s. 244.

${ }^{18} \mathrm{~W}$ języku polskim opowiadanie to znajduje się w zbiorze Omon Ra i inne opowieści (wyd. 2007), w oryginale w Żettaja Strieła, natomiast w języku angielskim w The Yellow Arrow (wyd. 1993).

${ }^{19}$ Co ciekawe, wykorzystywanie metafory pociągu nie jest obce buddyjskiej praktyce. Por. A. Przybysławski, Pustka jest radościa, czyli filozofia buddyjska z przymrużeniem (trzeciego) oka. Warszawa: Wydawnictwo Iskry, 2010, s. 153-169. 
tło słoneczne padało na obrus pokryty lepkimi plamami i okruszynami, i Andriej pomyślał nagle, że dla milionów promieni jest to prawdziwa tragedia rozpocząć drogę na powierzchni słońca, przemknąć przez wielokilometrowe niebo - a wszystko tylko po to, by zgasnąć na obrzydliwych resztkach wczorajszej zupy. A przecież całkiem możliwe, że owe ukośnie padające $\mathrm{z}$ okna żółte strzały miały świadomość (...) - to jest, tak jak człowiek, rozporządzały wszystkimi elementami, niezbędnymi do tego, by cierpieć” ${ }^{20}$. Bohater później porównuje siebie do takiej żółtej strzały, a życie do brudnej szyby przez którą pada na stół. Dalej, Andriej zauważa na drzwiach zadrapanie w kształcie strzały - żółtej, gdyż są one zrobione z plastiku w tym właśnie kolorze. Jest to wejście do przedziału Chana, który przypomina protagoniście, że Żółta Strzała to... nazwa pociągu, którym wszyscy jadą. Być może imię tego przyjaciela ma odwoływać się do kultury mongolskiej i jej tradycji „wielkich chanów”, w której to podczas drugiej fali buddyzmu (XVI w.) nazywano go „żółtą religią” ze względu na dominację szkoły gelug, czyli Żółtych Czapek. Związki przywódców mongolskich z gelugpami podkreśla jeszcze fakt, że tytuł najwyższego zwierzchnika tej szkoły, czyli „dalajlama”, został nadany po raz pierwszy w 1578 r. przez Ałtan-chana (1507-1583).

Pociąg nie ma ani początku, ani końca. O tym, że jest jakaś lokomotywa świadczą, „oprócz mnóstwa wewnątrz-wagonowo-metafizycznych uzasadnień" ${ }^{21}$, miedziany kabel zainstalowany na dachu oraz słyszalne od czasu do czasu przeciągłe wycie. W nieznanej (nieskończonej?) liczbie wagonów żyją pasażerowie; korzystają ze wspólnych toalet, czekają w kolejkach, żywią się w restauracyjnym etc. Mieszkają tam całe rodziny, ludzie mają pracę, a dodatkowo miejsca w pociągu są zróżnicowane ze względu na standard. Kiedy ktoś umrze jego ciało jest po prostu wyrzucane za okno wraz z częścią dobytku. Dlatego też na widok z okna składają się głównie porozrzucane przedmioty codziennego użytku i śmieci poprzetykane czaszkami oraz kośćmi w różnych stadiach rozkładu: „Najwięcej zalegało oczywiście pustych butelek. (...) Czasem trafiały się przedmioty dość dziwne - na przykład w jednym miejscu z niewielkiego bagienka sterczał świeżo wbity w błoto obraz w ogromnej złotej ramie (...). Szczególnie wiele było czaszek (...). Niektóre czaszki, całkiem stare, były wypolerowane do kredowej białości przez deszcze i wiatr, a na świeższych pozostały jeszcze włosy i strzępki ciała. Andrieja

${ }^{20}$ Idem, Żótta Strzała. [w:] W. Pielewin, Omon Ra i inne opowieści, Wyd. I, Wydawnictwo W.A.B., Warszawa 2007, s. 173.

${ }^{21}$ Ibidem, s. 217. 
szczególnie rozśmieszyła jedna czaszka z błyszczącymi okularami, w których chyba nawet zachowały się szkła"22.

Najciekawsze jest to, iż wszyscy pasażerowie wiedzą, że pociąg zmierza do zrujnowanego mostu, ale mało kto przejmuje się tym faktem. Jest on uznawany za coś całkowicie zwyczajnego, wręcz naturalnego i niewymagającego głębszej refleksji. Co więcej, w pociągu na okrągło rozbrzmiewa urywająca się w połowie piosenka Bridge over Troubled Water. Prawdopodobnie jest ona jednak dla większości niezauważalnym tłem, podobnie jak wszechobecny stukot kół - prawie nikt już nie zwraca na niego uwagi, zapominając, że jedzie pociągiem. Co ciekawe, dźwięki te przypominają pitagorejską muzykę sfer, której nie słyszymy właśnie dlatego, że nigdy nie było w niej przerwy. $\mathrm{Na}$ początku utworu protagonista również odbiera stukot kół jako white noise. Dopiero rozmowa z Chanem pomaga mu wyjść z marazmu: „Zapamiętaj sobie: kiedy człowiek przestaje słyszeć stukot kół i zgadza się jechać dalej, staje się pasażerem"23. Andriej odpowiada na te słowa przyjaciela, iż nikt ludzi w pociągu nie pyta, czy zgadzają się jechać dalej, że nie mają wyjścia oraz, że nikt z nich nawet nie pamięta, jak się tu dostał. Wtedy Chan wypowiada chyba najważniejszą kwestię w całym utworze: „Pozostaje to, co w życiu najtrudniejsze. Jechać pociągiem i nie być jego pasażerem”24 „Normalny pasażer" nie patrzy jednak na siebie w tych kategoriach, dlatego też nie czuje potrzeby wysiadania - już zapomniał, że dokądkolwiek jedzie. Tylko świadomość, że jest się pasażerem, daje szansę na opuszczenie pociągu. Warto też wiedzieć, iż Żółta Strzała może się zatrzymać i to przed zrujnowanym mostem. Powrócę teraz do bardzo ważnej kwestii wspomnianego stukotu kół.

Pewnego dnia protagonista natyka się na artykuł pt. Antropologia totalna, w którym to znajduje się przegląd imitacji dźwięku kół pociągu w różnych językach. Publikacja podaje, iż przez niektórych badaczy są one wręcz traktowane jako „hasła kulturowe” pozwalające na rozpoznanie sąsiadów z wagonu. Na szczególną uwagę zasługuje tu kolejowa onomatopeja w języku tybetańskim, gdyż brzmi ona $d z o g$-czen. Ją właśnie wykorzystam jako klucz do odczytania utworu. Dzogczen oznacza dosłownie „wielką doskonałość” lub „wielkie wyczerpanie” w rozumieniu pozbycia się wszelkich zasłon umysłu. Termin ten można jednak rozumieć wielorako, dlatego tutaj odniosę się jedynie do dwóch jego znaczeń: synonimu atijoga tantry lub osobnego systemu nauk i praktyk prowadzącego do wyzwolenia.

\footnotetext{
${ }^{22}$ Ibidem, s. 232-233.

${ }^{23}$ Ibidem, s. 183.

${ }^{24}$ Ibidem, s. 183 .
} 
Atijoga tantra jest najwyższą z trzech klas wewnętrznych (wyższych) tantr buddyjskich według podziału ningmapy. Wcześniejsze to mahajoga tantra i anujoga tantra: „Hierarchia tych trzech [klas wewnętrznych - przyp. A.I.] opiera się na rosnącej głębi i subtelności nauk oraz praktyk, począwszy od wizualizacji, poprzez wgląd w naturę rzeczywistości, a skończywszy na jedności zjawisk i pustki” "25. Do trzech klas zewnętrznych należą krija tantra, czarja tantra oraz joga tantra. Atijoga jest również najwyższym z dziewięciu pojazdów (yana) stanowiących podział całości nauk buddyjskich według ningmapów. Trzy najniższe to pojazdy sutr: związane z wczesnym buddyzmem; śrawakajana (pojazd słuchaczy) i pratjekabuddajana (pojazd buddów indywidualnych) oraz związana z mahajaną bodhisattwajana (pojazd bodhisattwów). Sześć kolejnych to wymienione już klasy tantr zewnętrznych i wewnętrznych.

Tradycja tybetańska przypisuje początki dzogczen postaci Garaba Dordże, który miał mieć wizje pochodzące od Wadżrasattwy. Do Tybetu nauki te dotarły za sprawą Padmasambhawy i stały się częścią ningmapy. Według dzogczen pustka i zjawiska wzajemnie się przenikają, są nieoddzielne. Medytujący nie stosuje wizualizacji czy wizerunków, ale bezpośrednio skupia się na naturze umysłu. Jest to natura czystego światła, które istotowo pozostaje zawsze wolne od splamień. Jest to inaczej „sam umysł” równoznaczny z naturą buddy, która występuje u każdej istoty czującej. Tworzy on podstawę dla „zwykłego umysłu”, czyli uwikłanego w myślenie konceptualne, skażonego dualizmem podmiot-przedmiot. Dzogczen oferuje stosunkowo szybką ścieżkę do oświecenia, lecz jednocześnie jest ona właściwa dla niewielu adeptów, gdyż wymaga ogromnych zdolności i zaawansowanego rozwoju duchowego. Jak podaje Powers: „Jedną z podstawowych przeszkód jest to, że czysta świadomość jest tak wszechobecna i tak fundamentalna, że trudno ją dostrzec" ${ }^{26}$. Nierozpoznanie, w jaki sposób jest w niej zakorzeniona ludzka świadomość, powoduje cierpienie w sansarze.

Ma to związek z Pielewinowską koncepcją pasażera i niezauważania tego właśnie własnego statusu w stosunku do jadącego pociągu. Idąc dalej, w praktyce dzogczen niezbędny jest nauczyciel, który sam zrealizował naturę umysłu, dzięki czemu może w bezpośrednim kontakcie wskazać ją adeptowi. W opowiadaniu relacji mistrz-uczeń można się dopatrzeć między Cha-

${ }_{25}^{5}$ J. Powers, Wprowadzenie do buddyzmu tybetańskiego, Wydawnictwo A, Kraków 1999, s. 347.

${ }^{26}$ Ibidem, s. 353 . 
nem a Andriejem ${ }^{27}$. Przyjaciel daje protagoniście wiele wskazówek. Po pierwsze, jak już zdążyłam wspomnieć, uświadamia mu, że Żółta Strzała to pociąg i chodzi o to, aby nim jechać, nie będąc pasażerem. Co więcej mówi: „Jeżeli nie będziemy sami siebie oszukiwać, natychmiast oszukają nas inni. A tak w ogóle, umieć oszukać to, co nazywasz samym soba, to wielkie osiągnięcie, bo zazwyczaj dzieje się na odwrót - to ono nas oszukuje. A czy istnieje coś poza naszym pociągiem, czy nie istnieje, to zupełnie nieważne. Ważne, że można żyć tak, jakby to coś istniało. Jakby z pociągu rzeczywiście można było wysiąść. Na tym polega cała różnica" ${ }^{28}$. Znajdujemy tu nawiązanie do porzucenia przywiązania do buddyjskiej koncepcji podmiotu jako iluzji. Jest on pusty, iluzoryczny, a jednak udaje mu się „nas oszukać”, że istnieje.

Trzeba jednak wspomnieć, że w pociągu są też grupy ludzi zdające sobie sprawę z odbywającej się podróży, a co za tym idzie, poszukujące duchowej ścieżki. Należą oni do różnorakich stowarzyszeń, sekt, pomniejszych wyznań. Jedną z ciekawszych religii jest utrizm, według którego pociąg ciągnięty jest przez lokomotywę U-3. Ponadto, jedynie jego wyznawcy zdołają przejechać po ostatnim moście w stronę świetlistego poranka. Jak dowiadujemy się z przypisu tłumaczki, rosyjskie U-tri nawiązuje do słowa utro, czyli właśnie „poranek”. Spora część „poszukiwaczy mistycznych wrażeń” spotyka się co jakiś czas na dachu pociągu. Niektórzy palą fajki, inni grają na instrumentach, kolejni, zakapturzeni i w habitach, siedzą kręgiem wokół narysowanych przez siebie figur geometrycznych. Właśnie w takich okolicznościach poznali się Andriej z Chanem. Ten jednak uważa, iż wychodzenie na dach jest tak naprawdę szkodliwe i jedynie oddala od możliwości opuszczenia pociągu. Być może owo wychodzenie na dach jest metaforą stanów transowych, w które można się wprowadzić chociażby za pomocą dźwięku lub praktyk magicznych, kiedy próbuje się wejść w kontakt z określonym bóstwem - tutaj akurat w stylu neopogańskiego nurtu Wicca. Nawet książki okultystyczne sprzedawane w wagonie restauracyjnym są pisane przez osoby porównujące tę czynność do „rytualnej śmierci”. Awersja Chana mogłaby zatem być motywowana niechęcią do rozwijania złego poglądu dotyczącego natury rzeczywistości. Czysta świadomość jest wszędzie i przez cały czas dostępna, zatem wyzwolenie daje uważne postrzeganie, bez chcenia, starania się, oczekiwań. Jak pisze Volker Zotz, dzogczen jest pojmowany jako „bezpośrednie urzeczywistnienie czystego postrzegania, do którego nie moż-

\footnotetext{
${ }^{27}$ Taką relację mają również bohaterowie Małego palca Buddy Czapajew i Pusto.

${ }^{28}$ W. Pielewin, Żótta Strzała, s. 182.
} 
na zmierzać"29. To niedziałanie podobne do taoistycznego wuwei, skutkuje brakiem podziału na medytację i nie-medytację. Słysząc taki właśnie stukot kół, ciągle przypominający o wszechobecnej naturze buddy, Tybetańczycy zapewne bardzo szybko opuścili Żółtą Strzałę.

Trzeba zaznaczyć, że zainteresowanie Andrieja faktem, skąd jedzie pociąg, Chan zbywa, kładąc nacisk na problem jego opuszczenia. Widać tu charakterystyczny dla buddyzmu akcent położony na kwestie soteriologiczne. Taką postawę znajdujemy już w naukach Buddy Śakjamuniego: „Krytykował teoretyzowanie o powstaniu i końcu świata, jego skończoności lub nieskończoności, pochodzeniu człowieka czy też pośmiertnej egzystencji wyzwolonego. Obchodził go nie tyle obraz świata dający odpowiedź na wszystkie pytania, ile doświadczenie wyzwolenia z bolesnej nietrwałości” ${ }^{30}$.

Co więcej, takiej postawy można się dopatrzeć również w „liście” pokazanym Andriejowi przez przyjaciela. Chan wychodzi z założenia, że wszędzie pełno jest wiadomości-wskazówek w przeróżnej formie przekazywanych pasażerom, ci jednak zwyczajnie ich nie dostrzegają. Jedną z nich, dającą kolejną możliwość odczytania tytułu opowiadania, jest napis wydrapany na ścianie w starym, opuszczonym wagonie:

TEN, KTO ODRZUCIE ŚWIAT, ZRÓWNAŁ GO Z ŻÓ£TYM PYŁEM.

TWOJE CIAŁO JEST PODOBNE DO RANY, A TY SAM

JESTES PODOBNY DO SZALEŃCA.

CAŁY TEN ŚWIAT

TO ŻÓ£TA STRZAŁA, KTÓRA CIĘ UGODZIŁA.

ŻÓ£TA STRZAŁA, POCIĄG, KTÓRYM JEDZIESZ

DO ZRUJNOWANEGO MOSTU ${ }^{31}$.

Widzimy tu kolejne nawiązanie do słów Buddy Śakjamuniego, będących odpowiedzią na wątpliwości jednego ze swoich uczniów dotyczące natury rzeczywistości, wiecznego istnienia świata etc.: „To jest tak, o Mālunkyāputto, jak gdyby pewnego człowieka zraniła strzała posmarowana trucizną, a jego przyjaciele i towarzysze, krewni i powinowaci poszli znaleźć dlań lekarza

${ }^{29}$ V. Zotz, op. cit., s. 236.

${ }^{30}$ Ibidem, s. 37 .

${ }^{31}$ W. Pielewin, Żótta Strzała, s. 196. 
lub chirurga, ów zaś chory człowiek mówiłby: nie chcę, by wyciagnięto mi te strzałę, zanim się nie dowiem, czy człowiek, który mnie zranil, byt kszatrija, braminem, wajśją bądź śudra. (...) Ten człowiek, Mālunkyāputto, umarłby, zanim by się tego wszystkiego dowiedzial" ${ }^{2}$. Istotne jest zatem koncentrowanie się na informacji i dociekaniu, które ma ostatecznie wyzwalający charakter i umiejętność oddzielenia informacji ważnych od nieważnych, bo uczeń Buddy nie potrafił tego zrobić zadając nieważne pytania.

Wyzwolenie równa się poznaniu natury rzeczywistości taką jaka ona jest, a jest... niewyrażalna. Pielewin jest całkowicie świadomy tego faktu, co pokazuje chociażby w powieści $T$ : „,naszej ukrytej natury nie można wyrazić słowami z tego samego powodu, z którego ciszy nie można zagrać na bałałajce"33. Stanowi to nie lada problem dla pisarza, jako osoby pracującej właśnie na materii językowej. Nie zapominajmy jednak, że chodzi tu o świat literatury, który rządzi się swoimi własnymi prawami, wkraczając w jego granice warto porzucić pryzmat patrzenia na rzeczywistość w kategorii prawdy i fałszu, gdyż to jedynie zaciemnia dotarcie do znaczenia komunikatu. Niewyrażalność oświecenia autor „obchodzi” poprzez metaforę opuszczenia pociągu, której się teraz dokładniej przyjrzę.

Po ostatnim wspólnym wyjściu na dach Chan znika w niewyjaśnionych okolicznościach (wysiadł?), zostawiając dla Andrieja list tej oto treści:

W dawnych czasach ludzie spierali się często, czy istnieje lokomotywa, która ciągnie nas za sobą w przyszłość. Zdarzało się, że dzielili przyszłość na swoją i cudzą. Ale to już zostało za nami: życie idzie naprzód, a oni, jak widzisz, zniknęli. A co jest w górze? Ślepy gmach za oknem gubi się w falach lat. Potrzebny jest klucz, a ty masz go w ręku - więc jak go znajdziesz i komu okażesz? Jedziemy pod stukot kół, wysiadamy

postscriptum drzwi ${ }^{34}$

Następnie napotykamy opis protagonisty wyglądającego przez okno. Po raz pierwszy na zewnątrz widać ludzi, a dokładnie rzecz biorąc, żywych ludzi, którzy dodatkowo patrzą na niego. Nie mogąc znieść tej sytuacji, Andriej zaczyna spacerować po pociągu. Żółta Strzała wygląda jednak inaczej niż zwykle: podłogę pokrywa gruba warstwa kurzu, drzwi do wszystkich przedziałów są pootwierane, wewnątrz stoją tylko metalowe szkielety mebli, nie

${ }^{32}$ I. Kania, Muttāvali. Księga wypisów starobuddyjskich, Oficyna Literacka, Kraków 1999, s. 73. ${ }^{33}$ W. Pielewin, T, s. 328.

${ }^{34}$ Idem, Żótta Strzała, s. 235-236. 
ma nikogo. Ta ostatnia informacja napełnia jednak bohatera spokojem i po raz kolejny czyta on otrzymany list:

PRZESZŁOŚĆ TO LOKOMOTYWA,
KTÓRA CIĄGNIE ZA SOBĄ W PRZYSZŁOŚĆ.

ZDARZA SIĘ, ŻE TA PRZESZŁOŚĆ JEST

NA DODATEK CUDZA.

SIEDZISZ TYŁEM DO KIERUNKU JAZDY

I WIDZISZ TYLKO TO, CO JUŻ ZNIKŁO.

A ŻEBY WYSIĄŚĆ Z POCIĄGU, POTRZEBNY JEST BILET.

MASZ GO W RĘKU, ALE KOMU GO OKAŻESZ? ${ }^{35}$

Od razu da się zauważyć, że wiadomość, przypominająca zresztą zenistyczny koan, nie jest taka sama jak poprzednim razem. Zmieniony widok za oknem, ale i odmienne, opustoszałe wnętrze pociągu mogą wprawić czytelnika w konsternację, ale po chwili dowiadujemy się, że był to jedynie sen bohatera. Odwołam się tu do obrazu Salvadora Dalí pt. Sen spowodowany lotem pszczoty wokót jabtka granatu na jedna sekunde przed przebudzeniem. Przedstawia on wizję senną, prawdopodobnie kobiety widniejącej na płótnie, na sekundę przed jej obudzeniem się. Być może marzenie to zostanie zapamiętane. Podobnie Andriej, w momencie przechodzenia ze świata snu na jawę, zapamiętuje dopisek do wiadomości: „PS Cała rzecz w tym, że stale wyruszamy w podróż, która zakończyła się na sekundę przedtem, zanim zdążyliśmy wyjechać ${ }^{36}$ ". Po całkowitym przebudzeniu się protagonista zdaje sobie sprawę, że nie słyszy stukotu kół, gdyż pociąg stoi w miejscu. $\mathrm{Na}$ pierwszy rzut oka wszystko wygląda identycznie jak zwykle, tyle że wszyscy okazują się być nieruchomi. Andriej zabiera konduktorowi klucz, otwiera zamknięte od dawna drzwi pociągu, przez moment chce wrócić po jakiś

\footnotetext{
35 Ibidem, s. 238.

${ }^{36}$ Ibidem, s. 239; por. A. Przybysławski, Pustka jest radościq..., s. 169: „Zaczynamy więc i kończymy dokładnie tu, gdzie jesteśmy, dokładnie tu i teraz. Nasz pociąg nie musi w ogóle odjeżdżać z tej stacji, bo to właśnie jest stacja docelowa.”.
} 
bagaż, ale dochodzi do wniosku, że to absolutnie mu się nie przyda: „Stanął na skraju żebrowanego żelaznego stopnia i popatrzył w ciemność. Była nieskończona i cicha; przyleciał z niej ciepły wiatr, pełen mnóstwa nieznanych zapachów"37. Chwilę po tym jak protagonista wysiada pociąg rusza na nowo. Z zewnątrz naprawdę wygląda jak żółta strzała - nie wiadomo dokąd zmierza, nie wiadomo kto ją wystrzelił.

W tym momencie czytelnik może mieć poczucie, że opowiadanie mogłoby się zakończyć. Autor jednak kontynuuje przedstawienie swojej wizji wyzwolenia. Bohater kroczy przed siebie, bez wyraźnego celu, idzie szosą otoczoną polami i po raz pierwszy w życiu słyszy szum wiatru, ćwierkot w trawie.

Bardzo ciekawa próba literackiego uchwycenia oświecenia występuje również w Matym palcu Buddy. W powieści tej jest ono utożsamiane z dotarciem do Mongolii Wewnętrznej: „Jest wewnątrz tego, kto widzi pustkę, chociaż słowo wewnątrz wcale tu nie pasuje. I w ogóle to żadna Mongolia, po prostu tak się mówi. Najgłupszą rzeczą byłoby próbować opisać panu, co to właściwie jest” ${ }^{8}$. Wiemy jednak, że protagonista się tam dostał: „(...) jechaliśmy coraz szybciej i niebawem szeleściły już wokół piaski i szumiały wodospady drogiej memu sercu Mongolii Wewnętrznej"39.

Można odnieść wrażenie, iż Pielewin w momentach zbliżania się do opisu rzeczywistości takiej, jaką jest, wykorzystuje samą naturę. Natura jest wszechobecna, choć tak często właśnie niedostrzegana, cywilizacja, kultura odciągają od niej uwagę. Daje to moim zdaniem poczucie, jakby właśnie w niej zapisana była cała prawda i nie ma tu niczego więcej do dodania. Potwierdzeniem tych poglądów mogą być słowa protagonisty Małego palca Buddy: „(...) podczas gdy idioci-dorośli zajmują się przebudową wymyślonego przez nich świata, dzieci żyją w rzeczywistym świecie - pośród ośnieżonych gór i słonecznego blasku, na czarnych lustrach zamarzniętych wód i w mistycznej ciszy (...) w ich czystych oczach wciąż jeszcze jaśniała pamięć czegoś, o czym ja dawno już zapomniałem - (...) pamięć o wielkim źródle wszechrzeczy $(. .). "{ }^{\prime 0}$. Podobny motyw napotykamy w powieści $T$. W końcowym opisie główną rolę odgrywa mały, zielony robaczek siedzący na źdźble trawy. Pociera on o siebie łapki na kształt modlitwy do słońca: „Zapewne nie było w

\footnotetext{
37 Ibidem, s. 240.

${ }^{38}$ Idem, Maty palec Buddy, s. 276.

${ }^{39}$ Ibidem, s. 393 .

${ }^{40}$ Ibidem, s. $85^{-86 .}$
} 
tych ruchach żadnego sensu. A może żuczek chciał powiedzieć, że jest niczym w porównaniu z malinową kulą słońca (...). Ale dziwne było co innego - że to ogromne słońce wraz ze wszystkimi na świecie w jakiś zdumiewający sposób powstaje i znika w owym drobniutkim stworzonku, siedzącym w strumieniu słonecznego blasku. A zatem nie sposób powiedzieć, czym w istocie jest ten żuczek, to słońce (...) - jako że wszelkie słowa byłyby głupotą, snem i pomyłką. I o wszystkim tym mówiły jasno ruchy czterech łapek, cichy szelest wiatru w trawie i nawet cisza, która zapadła, kiedy wiatr ustał" ${ }^{1}$. Zatem Pielewin nie opisuje, ale sugeruje. Dlatego właśnie jego język staje się poetycką prozą. Autor balansuje między rzeczywistościami, wykorzystując stylistykę oniryczną i odsyła do znanych obrazów, by podkreślić jeszcze „naturalnośćc oświecenia.

${ }^{41}$ Idem, $T$, s. 406. 


\section{Bibliografia}

1. Berlina, A., Russian Magical Realism and Pelevin as Its Exponent, „Comparative Literature and Culture" 11 (4/2009), [www 01] (dostęp: 15.12.2015).

2. ImosA, A., Buddyzm w literaturze na przykładzie opowiadania „Iwan Kublachanow” Wiktora Pielewina, „Ogrody Nauk i Sztuk” 5 (2015), s. 536-537, [www 02] (dostęp: 15.10.2016).

3. Kania, I., Muttāvali. Księga wypisów starobuddyjskich, Oficyna Literacka, Kraków 1999.

4. Perec, G., Un homme qui dort, Denoël, Paryż 1967.

5. Pielewin, W., Maty palec Buddy, Wyd. I, Wydawnictwo W.A.B., Warszawa 2003.

6. Pielewin, W., SPI [w:] W. Pielewin, Kryształowy świat, Wyd. I, Wydawnictwo W.A.B., Warszawa 2008, s. 277-302.

7. Pielewin, W., T, Wyd. I, Wydawnictwo W.A.B., Warszawa 2012.

8. Pielewin, W., Żótta Strzała, [w:] W. Pielewin, Omon Ra i inne opowieści, Wyd. I, Wydawnictwo W.A.B., Warszawa 2007.

9. Powers, J., Wprowadzenie do buddyzmu tybetańskiego, Wydawnictwo A, Kraków 1999.

10. PrzybysŁawski, A., Pustka jest radościa, czyli filozofia buddyjska z przymrużeniem (trzeciego) oka, Wydawnictwo Iskry, Warszawa 2010.

11. Zotz, V., Historia filozofii buddyjskiej, Wydawnictwo WAM, Kraków 2007.

\section{Wykorzystane źródła internetowe:}

[www 01 ] http://docs.lib.purdue.edu/clcweb/vol11/iss4/7/

[www 02] http://www.ogrodynauk.pl/lista-wydan/5-2015/ 


\title{
Abstract, keywords, about the author
}

\begin{abstract}
The subject of this article brings together the literary theory and the cultural studies as it concerns introduction of the Buddhist elements into literature. Chosen novels and short stories written by contemporary Russian writer Victor Pelevin are studied (paradoxically) in the light of the description of the indescribable phenomenon which is Enlightenment.
\end{abstract}

Keywords: Victor Pelevin, Buddhism, Enlightenment, Nirvana, Sansara

Aleksandra Imos A comparatist of civilisations, student of Romance Philology at Jagiellonian University, in the first place her scientific interests include the analysis of Buddhist elements in contemporary literature, but at the moment she's also analysing the description of Buddhism, Nestorian Church and Islam in the 13th century "Description of the World" ("Le Devisement du monde") by Marco Polo.

Affiliation: Institute of Romance Studies, Jagiellonian University, Cracov, Poland.

E-MAIL: imosa.aleksandra@gmail.com 